\title{
13. OXYGEN ISOTOPIC COMPOSITION OF INTERSTITIAL WATERS FROM LEG 154: DETERMINATION OF THE TEMPERATURE AND ISOTOPIC COMPOSITION OF THE GLACIAL OCEAN ${ }^{1}$
}

\author{
Daniel P. Schrag, ${ }^{2}$ Gretchen Hampt, ${ }^{3}$ and David W. Murray ${ }^{4}$
}

\begin{abstract}
Oxygen isotope measurements of interstitial waters from Ocean Drilling Program Leg 154, sampled at high resolution from Sites 925 and 929, are used to reconstruct the oxygen isotopic composition of deep water during the last glacial maximum (LGM). The data from both sites show an increase with depth, predicted by modeling the diffusion of water through the sediment, although only data from Hole 925E are appropriate for calculating the composition of seawater during the LGM. Using a numerical model to simulate diffusion of water in the sediments, we obtained a glacial-interglacial change in the $\delta^{18} \mathrm{O}$ of seawater at Site 925 of $0.8 \pm 0.1 \%$. This implies that the bottom water at Site 925 cooled by approximately $4^{\circ} \mathrm{C}$ during the LGM. Although these data from a single site do not represent a global average, we suggest that the substantial cooling of deep water at Site 925 is consistent with a global average change in the $\delta^{18} \mathrm{O}$ of seawater of $1.0 \%$. This value is within the limits imposed by the freezing point of seawater and is more consistent with estimates of the $\delta^{18} \mathrm{O}$ of continental ice during the glacial maximum. In addition, a lower contribution from ice volume to the change in $\delta^{18} \mathrm{O}$ of planktonic foraminifers allows for $1^{\circ}-2^{\circ}$ additional cooling in the tropics during the LGM, partially reconciling the foraminiferal oxygen isotope record of tropical sea surface temperatures with estimates from Barbados corals and terrestrial climate proxies.
\end{abstract}

\section{INTRODUCTION}

Pleistocene oxygen isotope records of foraminifers in deep sea sediments reflect changes in ocean temperature and in the oxygen isotopic composition of seawater $\left(\delta^{18} \mathrm{O}_{\text {sw }}\right)$ over glacial cycles. Cooling during glacial episodes increases the mass-dependent fractionation of oxygen isotopes between water and calcite, resulting in higher $\delta^{18} \mathrm{O}$ values of carbonate microfossils. The growth of large ice sheets on continents enriches seawater in ${ }^{18} \mathrm{O}$, which also results in higher $\delta^{18} \mathrm{O}$ values for carbonate microfossils. Determining how much each of these components contributes to the total change in $\delta^{18} \mathrm{O}$ of foraminifers since the last glacial maximum (LGM), which for benthic foraminifers averages $1.7 \%$ (Broecker, 1986), is an important step toward understanding Pleistocene climate change.

Schrag and DePaolo (1993) presented a method for determining the ice volume component of the carbonate $\delta^{18} \mathrm{O}$ record interstitial waters from deep sea sediment. The changes in $\delta^{18} \mathrm{O}_{\mathrm{sw}}$ caused by changes in continental ice volume represent a periodic upper boundary condition for the sediment-interstitial water system. These changes diffuse down from the seafloor, leaving a profile of $\delta^{18} \mathrm{O} v \mathrm{vs}$. depth in the interstitial water that is a record of the $\delta^{18} \mathrm{O}$ history of the overlying seawater. The magnitude of the self-diffusion of water in deepsea sediments is such that modern interstitial water preserves little record of the $\delta^{18} \mathrm{O}$ history of the ocean at the frequency of glacial cycles, except for the large $\delta^{18} \mathrm{O}$ shift associated with the last deglaciation. Because oceanic deep water is isotopically less variable than surface water, this method eliminates the uncertainties associated with previous determinations that measured surface water $\delta^{18} \mathrm{O}$ variations (Fairbanks and Matthews, 1978; Shemesh et al., 1992).

${ }^{1}$ Shackleton, N.J., Curry, W.B., Richter, C., and Bralower, T.J. (Eds.), 1997. Proc. ODP, Sci. Results, 154: College Station, TX (Ocean Drilling Program).

${ }^{2}$ Department of Geological and Geophysical Sciences, Princeton University, Princeton, NJ 08544-1003, U.S.A. schrag@geo.princeton.edu

${ }^{3}$ Institute of Marine Sciences, University of California at Santa Cruz, Santa Cruz, CA 95064 , U.S.A.

${ }^{4}$ Department of Geological Sciences, Brown University, Providence, RI 02912, U.S.A.
Schrag and DePaolo (1993) calculated a glacial-interglacial change in $\delta^{18} \mathrm{O}_{\mathrm{sw}}$ of $1.0 \pm 0.25 \%$ using interstitial water data from Deep Sea Drilling Project (DSDP) Site 576 in the western Pacific (McDuff, 1985), although the precision of the calculation was limited by poor sampling resolution (1 sample every $9 \mathrm{~m}$ ) and low analytical precision $( \pm 0.1 \%$ ). During Leg 154 , interstitial waters were sampled from every section in the first $50 \mathrm{~m}$ for two holes (925E and 929A) to improve this determination with higher resolution data. In this paper, we present oxygen isotope data on all interstitial water samples collected during Leg 154, focusing primarily on Hole 925E.

\section{ANALYTICAL PROCEDURE}

Interstitial waters were squeezed from whole round samples from all sites following standard ODP procedures. Glass ampules containing $5 \mathrm{~cm}^{3}$ of each sample were sealed and transported to the Princeton Stable Isotope Laboratory for analysis. Samples from Hole 925E were divided in two, and both splits were loaded into glass vessels for analysis using a modified VG Isoprep18 automated Shaker/Equilibrator. All other samples were analyzed once. Samples were equilibrated with approximately $100 \mu \mathrm{mol}$ of $\mathrm{CO}_{2}$ at $25^{\circ} \mathrm{C}$ for $24 \mathrm{hr}$ before analysis on a VG Optima gas source mass spectrometer. Following analysis, samples from Hole 925E were equilibrated with a fresh injection of $\mathrm{CO}_{2}$ and re-analyzed. This method provides four replicate analyses for each sample from this hole. Standard deviations based on the four replicates of each sample from Hole $925 \mathrm{E}$ range from $0.01 \%$ o to $0.05 \%$ (Table 1 ). The overall precision is $0.03 \%$, calculated as the standard deviation $(1 \sigma)$ of 30 replicate analyses of standard water analyzed at the same time as the interstitial water samples. The accuracy of the reported values relative to SMOW is $0.05 \%$ o based on calibration of our in-house standard water with VSMOW. Data from all sites other than 925E are presented in Table 2.

\section{RESULTS}

The data from all sites are presented in two graphs in Figure 1, with one showing all values and the other showing an expanded view 
Table 1. Oxygen isotope data for interstitial water from Hole 925E.

\begin{tabular}{|c|c|c|c|c|c|c|c|}
\hline $\begin{array}{l}\text { Core, section, } \\
\text { interval }(\mathrm{cm})\end{array}$ & $\begin{array}{l}\text { Composite } \\
\text { depth } \\
(\mathrm{mcd})\end{array}$ & $\begin{array}{c}\delta^{18} \mathrm{O}(1) \\
(\% \circ \mathrm{SMOW})\end{array}$ & $\begin{array}{c}\delta^{18} \mathrm{O}(2) \\
(\% \circ \mathrm{SMOW})\end{array}$ & $\begin{array}{c}\delta^{18} \mathrm{O}(3) \\
(\% \circ \mathrm{SMOW})\end{array}$ & $\begin{array}{c}\delta^{18} \mathrm{O}(4) \\
(\% \circ \mathrm{SMOW})\end{array}$ & $\begin{array}{c}\delta^{18} \mathrm{O}_{\text {mean }} \\
(\% \circ \mathrm{SMOW})\end{array}$ & $\begin{array}{c}\text { SD } \\
( \pm 1 \sigma)\end{array}$ \\
\hline \multicolumn{8}{|l|}{ 154-925E- } \\
\hline $1 \mathrm{H}-1,145-150$ & 1.43 & 0.01 & -0.07 & 0.01 & -0.04 & -0.02 & 0.04 \\
\hline $1 \mathrm{H}-2,145-150$ & 2.93 & -0.04 & 0.00 & -0.03 & -0.02 & -0.02 & 0.02 \\
\hline $1 \mathrm{H}-3,145-150$ & 4.43 & -0.01 & -0.01 & -0.02 & -0.04 & -0.02 & 0.01 \\
\hline $1 \mathrm{H}-4,145-150$ & 5.93 & 0.01 & 0.01 & -0.06 & 0.01 & -0.01 & 0.03 \\
\hline $2 \mathrm{H}-1,145-150$ & 9.28 & -0.01 & 0.02 & -0.06 & 0.02 & -0.01 & 0.04 \\
\hline $2 \mathrm{H}-2,145-150$ & 10.78 & 0.04 & 0.00 & 0.02 & -0.01 & 0.01 & 0.02 \\
\hline $2 \mathrm{H}-3,145-150$ & 12.28 & 0.06 & 0.06 & 0.03 & 0.06 & 0.05 & 0.02 \\
\hline $2 \mathrm{H}-4,145-150$ & 13.78 & 0.05 & 0.05 & 0.03 & 0.06 & 0.05 & 0.01 \\
\hline $2 \mathrm{H}-5,145-150$ & 15.28 & 0.03 & 0.08 & 0.05 & 0.04 & 0.05 & 0.02 \\
\hline $2 \mathrm{H}-6,145-150$ & 16.78 & 0.11 & 0.08 & 0.09 & 0.02 & & \\
\hline $3 \mathrm{H}-1,145-150$ & 20.47 & 0.16 & 0.19 & 0.18 & 0.19 & 0.18 & 0.02 \\
\hline $3 \mathrm{H}-2,145-150$ & 21.97 & 0.16 & 0.17 & 0.17 & 0.18 & 0.17 & 0.01 \\
\hline $3 \mathrm{H}-4,145-150$ & 24.97 & 0.16 & 0.21 & 0.16 & 0.22 & 0.19 & 0.03 \\
\hline $3 \mathrm{H}-5,145-150$ & 26.47 & 0.15 & 0.22 & 0.16 & 0.23 & 0.19 & 0.04 \\
\hline $3 \mathrm{H}-6,145-150$ & 27.97 & 0.17 & 0.17 & 0.17 & 0.00 & & \\
\hline $4 \mathrm{H}-1,145-150$ & 30.62 & 0.17 & 0.22 & 0.18 & 0.20 & 0.19 & 0.02 \\
\hline $4 \mathrm{H}-2,145-150$ & 32.12 & 0.17 & 0.16 & 0.17 & 0.20 & 0.18 & 0.02 \\
\hline $4 \mathrm{H}-3,145-150$ & 33.62 & 0.21 & 0.24 & 0.22 & 0.24 & 0.23 & 0.01 \\
\hline $4 \mathrm{H}-4,145-150$ & 35.12 & 0.17 & 0.20 & 0.19 & 0.20 & 0.19 & 0.01 \\
\hline $4 \mathrm{H}-5,145-150$ & 36.62 & 0.18 & 0.11 & 0.23 & 0.11 & 0.16 & 0.05 \\
\hline $4 \mathrm{H}-6,145-150$ & 38.12 & 0.15 & 0.07 & 0.06 & 0.13 & 0.10 & 0.04 \\
\hline $5 \mathrm{H}-1,145-150$ & 41.54 & 0.03 & 0.03 & 0.10 & 0.11 & 0.07 & 0.04 \\
\hline $5 \mathrm{H}-2,145-150$ & 43.04 & -0.03 & -0.01 & 0.05 & 0.01 & 0.00 & 0.03 \\
\hline $5 \mathrm{H}-3,145-150$ & 44.54 & 0.09 & 0.08 & 0.08 & 0.10 & 0.09 & 0.01 \\
\hline $5 \mathrm{H}-4,145-150$ & 46.04 & 0.06 & 0.10 & 0.07 & 0.11 & 0.08 & 0.02 \\
\hline $5 \mathrm{H}-5,145-150$ & 47.54 & 0.07 & 0.05 & 0.07 & 0.05 & 0.06 & 0.01 \\
\hline $5 \mathrm{H}-6,145-150$ & 49.04 & 0.03 & 0.05 & 0.04 & 0.11 & 0.06 & 0.03 \\
\hline $6 \mathrm{H}-1,145-150$ & 53.24 & 0.00 & 0.01 & 0.00 & 0.05 & 0.01 & 0.02 \\
\hline $6 \mathrm{H}-3,145-150$ & 56.24 & 0.05 & 0.05 & 0.07 & 0.01 & 0.04 & 0.02 \\
\hline $6 \mathrm{H}-5,145-150$ & 59.24 & -0.04 & -0.02 & -0.04 & -0.04 & -0.04 & 0.01 \\
\hline $6 \mathrm{H}-6,145-150$ & 60.74 & -0.03 & 0.02 & 0.04 & 0.00 & 0.01 & 0.02 \\
\hline
\end{tabular}

Notes: Numbers $1-4$ are indicative of the four replicate measurements at this hole. SD $=$ standard deviation

of the data in the top $60 \mathrm{~m}$. The $\delta^{18} \mathrm{O}$ values at the top of the holes exhibit a systematic decrease with increasing water depth. Sites 925 , 926 , and 927 , the shallower of the sites, have the highest $\delta^{18} \mathrm{O}$ values at the tops of the holes, consistent with the more dominant influence of North Atlantic Deep Water (NADW) at shallower depths, which is enriched in ${ }^{18} \mathrm{O}$ relative to Antarctic Bottom Water (AABW). The deeper sites, 928 and 929, have the lowest values, typical of greater influence of AABW.

Data from all sites show an increase in $\delta^{18} \mathrm{O}$ with depth over the first $50 \mathrm{~m}$, as predicted from the above discussion of the diffusion of the higher $\delta^{18} \mathrm{O}$ water from the LGM. Because the sampling resolution is low at Sites 926, 927, and 928, it is difficult to evaluate the magnitude of the increase with these data. For the two sites sampled at higher resolution, only Site 925 shows a clear trend. Data from Site 929 are scattered; $\delta^{18} \mathrm{O}$ values of samples from sections 1 and 4 in each core are approximately $0.5 \%$ o lower than samples from other sections in the same core. These samples were squeezed immediately following the core retrieval and may have been contaminated with the deionized water used to clean the squeezers. Because of this possible sampling artifact at Site 929, only data from Site 925 are used to calculate $\delta^{18} \mathrm{O}_{\text {sw }}$ during the LGM. This problem emphasizes the care that must be employed to obtain samples for high precision analysis of stable isotopes on interstitial waters.

Following the increase through the first $50 \mathrm{~m}$, the $\delta^{18} \mathrm{O}$ values decrease at all sites, which correlates with an increase in $\mathrm{Ca}$ and a decrease in Mg (Curry, Shackleton, Richter, et al., 1995). This pattern is typical of interstitial waters from ODP sites in general and can be attributed to low temperature alteration of basaltic basement (McDuff and Gieskes, 1976; Lawrence and Gieskes, 1981). There is a systematic decrease in slope of the $\delta^{18} \mathrm{O}$-depth profiles with increasing water depth. This may be due to more rapid basalt alteration at deeper sites which, being away from the crest of the Ceara Rise, may have higher temperatures at basement.

\section{THE $\delta^{18}$ O OF SEAWATER DURING THE LGM}

To calculate $\delta^{18} \mathrm{O}_{\mathrm{sw}}$ during the LGM, we examined data from Site 925 in Figure 2. As discussed above, there is a peak in $\delta^{18} \mathrm{O}$ with depth occurring between 20 and $35 \mathrm{~m}$. The $\delta^{18} \mathrm{O}$ values are constant at $-0.02 \%$ in the first $7 \mathrm{~m}$, perhaps due to drilling disturbance. From 10 to $20 \mathrm{~m}$, the $\delta^{18} \mathrm{O}$ values increase to $0.18 \%$, followed by a plateau from 20 to $35 \mathrm{~m}$. Below $35 \mathrm{~m}$, the $\delta^{18} \mathrm{O}$ values decrease to a minimum of $-1.80 \%$ at a depth of $607 \mathrm{~m}$.

\section{Modeling Approach}

Model calculations similar to those described by Schrag and DePaolo (1993) are used to calculate a glacial-interglacial change in $\delta^{18} \mathrm{O}_{\mathrm{sw}}$ from the interstitial water profiles. The parameters that vary between calculations are the advective velocity and the glacial-interglacial change in $\delta^{18} \mathrm{O}_{\mathrm{sw}}$. Sedimentation and chemical reaction are not considered because they are too slow over the time period of interest to affect the calculations. We use diffusion coefficients from measured values of the self-diffusion of water (Simpson and Carr, 1958), adjusted for tortuosity using the square of the porosity and a bottomwater temperature of $3^{\circ} \mathrm{C}$ (Curry, Shackleton, Richter, et al., 1995). Based on measured values, the $\delta^{18} \mathrm{O}$ of the interstitial water at the lower boundary is fixed at $-0.75 \%$ at a depth of $200 \mathrm{~m}$; the reconstructed glacial-interglacial change in $\delta^{18} \mathrm{O}_{\mathrm{sw}}$ is not sensitive to slight changes in this lower boundary condition. To simulate the periodic change in $\delta^{18} \mathrm{O}_{\mathrm{sw}}$ with time at the sediment-water interface, we use benthic $\delta^{18} \mathrm{O}$ records for ODP Site 677 (Shackleton and Hall, 1989) and Core V19-30 (Shackleton and Pisias, 1985). We assume that the relative contributions of temperature and $\delta^{18} \mathrm{O}_{\mathrm{sw}}$ to the benthic $\delta^{18} \mathrm{O}$ records are constant with time and adjust the amplitude of those records for multiple calculations with glacial-interglacial changes in $\delta^{18} \mathrm{O}_{\mathrm{sw}}$ of $0.7 \%$ o, $1.0 \%$ o, and $1.3 \%$ o. We calculate the decrease in $\delta^{18} \mathrm{O}_{\mathrm{sw}}$ 


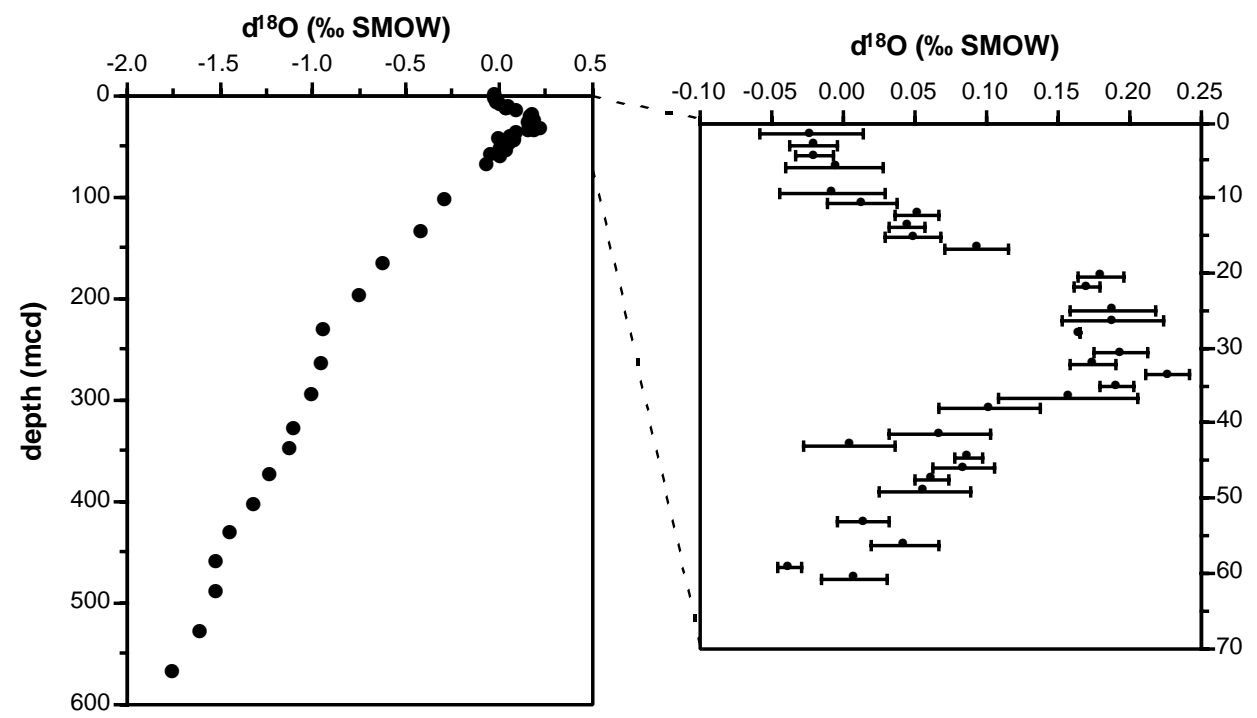

Figure 2. Oxygen isotope data on interstitial water from Site $925 \mathrm{vs}$. depth (mcd). Error bars for data in the upper $70 \mathrm{~m}$ represent one standard deviation of four replicate measurements (see Table 1).

over the last 20 k.y. of simulated time from the Fairbanks sea level curve (Fairbanks, 1989) using coral ages measured by U-Th disequilibria (Bard et al., 1990).

Figure 3 shows the comparison of the data with model results for a calculation with no advection. A best fit to the data is obtained by visual assessment for a glacial-interglacial change in $\delta^{18} \mathrm{O}_{\mathrm{sw}}$ between $0.7 \%$ and $0.8 \%$. Changing the diffusivity does not improve the fit. A higher diffusivity shifts the peak deeper in the hole and increases the attenuation of the signal; a lower diffusivity reduces the attenuation of the glacial-interglacial signal and implies a glacial-interglacial change in $\delta^{18} \mathrm{O}_{\mathrm{sw}}$ even smaller than $0.7 \%$ o. If upward advection is added to the system, the peak in the interstitial water $\delta^{18} \mathrm{O}$-depth profile is shifted upward, and the amplitude of the peak is attenuated, allowing for larger changes in $\delta^{18} \mathrm{O}_{\mathrm{sw}}$ (Fig. 4). However, the data deeper in the hole limit the magnitude of such flow. The $\delta^{18} \mathrm{O}$ gradient down to $570 \mathrm{~m}$ at Site 925 implies that advection, if present, is well below an advection velocity of $0.05 \mathrm{~mm} \mathrm{y}^{-1}$ (Fig. 4A). If we assume that the temperature of bottom water is constant from $115 \mathrm{ka}$ to $20 \mathrm{ka}$, and that changes in the benthic $\delta^{18} \mathrm{O}$ record reflect only changes in $\delta^{18} \mathrm{O}_{\mathrm{sw}}$, again of magnitude $0.7 \%$ o $1.0 \%$, and $1.3 \%$, then a glacial-interglacial change in $\delta^{18} \mathrm{O}_{\mathrm{sw}}$ of $0.9 \%$ will explain the data.

\section{DISCUSSION}

Overall, we estimate that the data from Site 925 are consistent with a glacial-interglacial change in $\delta^{18} \mathrm{O}_{\text {sw }}$ of $0.8 \pm 0.1 \%$. The glacial-interglacial difference in $\delta^{18} \mathrm{O}$ values of benthic foraminifers in the region of Site 925 is 1.8\%o (Curry and Lohmann, 1990). If the ice volume component of that difference is $0.8 \%$, then the temperature was $4^{\circ} \mathrm{C}$ colder during the LGM. As the modern potential temperature at $3 \mathrm{~km}$ water depth near Site 925 is $3^{\circ} \mathrm{C}$, the deep water during the LGM cooled to within one degree of its freezing point.

A glacial-interglacial change in $\delta^{18} \mathrm{O}_{\mathrm{sw}}$ of $0.8 \pm 0.1 \%$ o is surprising in that it is significantly different from the value of $1.3 \%$ o that is generally accepted as the global average (Guilderson et al., 1994; LynchStieglitz et al., 1994); it is also lower than the minimum value of $1.1 \%$ given by Duplessy (1978). The value of $1.3 \%$ o comes from work on Pleistocene corals from Barbados (Fairbanks and Matthews, 1978) and assumes that the change in tropical sea surface temperature was negligible during initial stages of deglaciations, consistent with

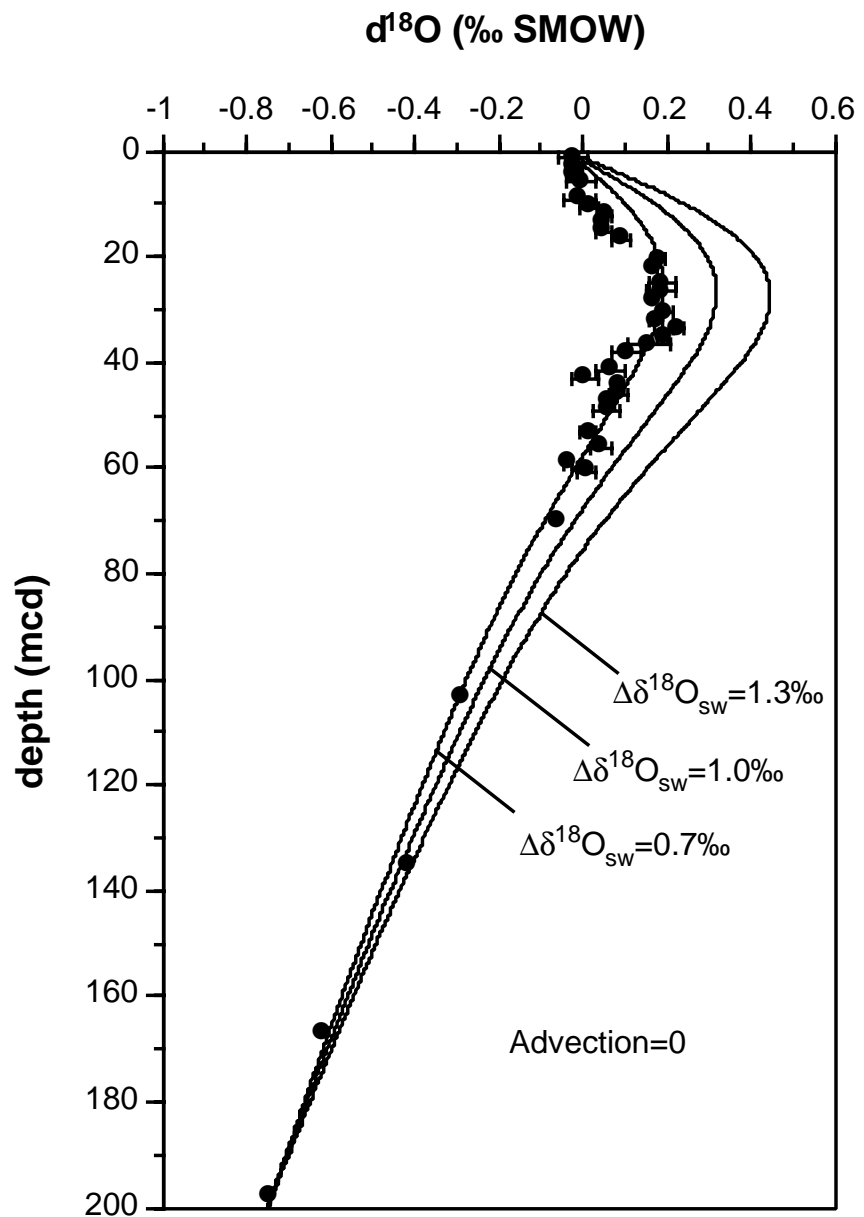

Figure 3. Comparison of interstitial water data and model calculations for different glacial-interglacial changes in $\delta^{18} \mathrm{O}_{\mathrm{sw}}$ with no advection. The best fit to the data is obtained for a change in $\delta^{18} \mathrm{O}_{\mathrm{sw}}$ of $0.7 \%$ - $-0.8 \%$. 
A

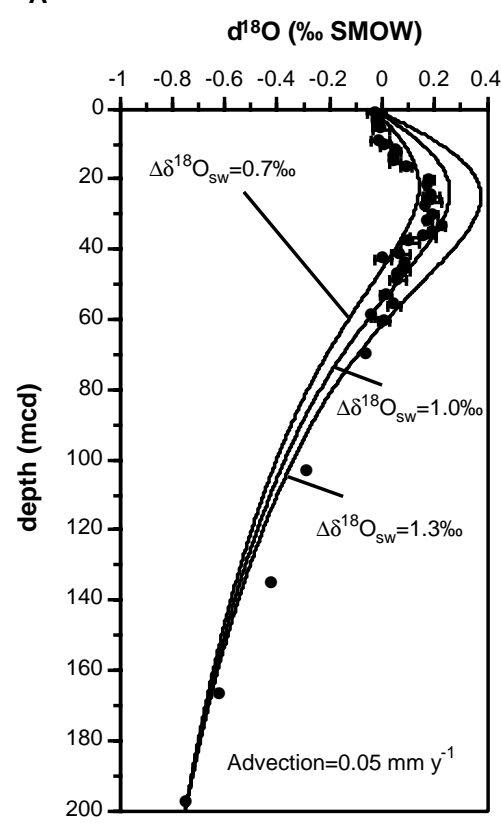

B

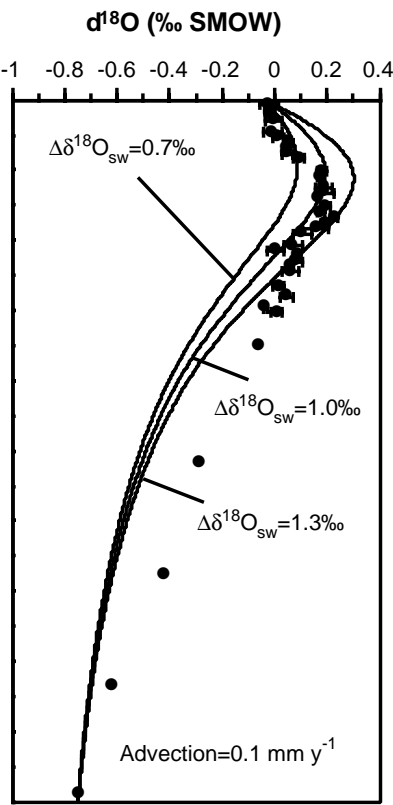

C $\mathrm{d}^{18} \mathrm{O}(\%$ SMOW)

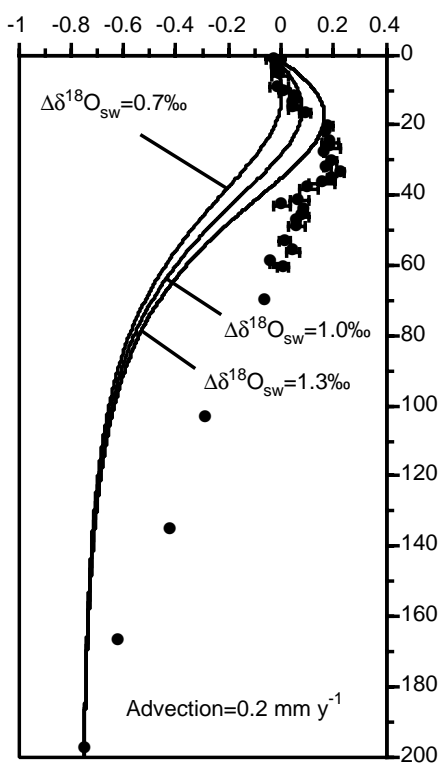

Figure 4. Comparison of interstitial water data and model calculations for different glacial-interglacial changes in $\delta^{18} \mathrm{O}_{\mathrm{sw}}$ with three different advection velocities, $0.05 \mathrm{~mm} \mathrm{y}^{-1}(\mathbf{A}), 0.10 \mathrm{~mm} \mathrm{y}^{-1}(\mathbf{B})$, and $0.20 \mathrm{~mm} \mathrm{y}^{-1}(\mathbf{C})$. For advection greater than $0.05 \mathrm{~mm} \mathrm{y}^{-1}$, the model curves do not reproduce the $\delta^{18} \mathrm{O}$-depth gradient that persists to the base of the hole.

the interpretation of CLIMAP that there was negligible net change in sea surface temperature in the tropics during the LGM (CLIMAP Project Members, 1981). However, Guilderson et al. (1994) report that sea surface temperatures at Barbados were $4.5^{\circ}-6^{\circ}$ colder during the LGM, based on the chemical and isotopic composition of corals. This is consistent with evidence from terrestrial climate proxies (Rind and Peteet, 1985; Stute et al., 1992; Porter, 1979; Webster and Streten, 1978; Van der Hammen, 1974). If Guilderson et al. (1994) are correct, even if their conclusion applies only to sea surface temperatures around Barbados, then it is likely that cooling contributes to the change in $\delta^{18} \mathrm{O}$ of Pleistocene corals from Barbados and that the maximum value of $1.3 \%$ is higher than the true global average ice volume contribution to the Pleistocene oxygen isotope record.

If we assume that seawater in the deep ocean was not frozen during the LGM, the difference between modern deep ocean temperature and the freezing point of seawater is the maximum contribution that temperature can make to the $\delta^{18} \mathrm{O}$ of foraminiferal carbonate, which sets a lower limit on the change in $\delta^{18} \mathrm{O}_{\mathrm{sw}}$. Duplessy (1978) uses this strategy for a southern Indian Ocean site with bottom-water temperature of $0.6^{\circ} \mathrm{C}$ and a glacial-interglacial change in the $\delta^{18} \mathrm{O}$ of benthic foraminifers of $1.65 \%$, setting the minimum glacial-interglacial change in $\delta^{18} \mathrm{O}_{\mathrm{sw}}$ at $1.1 \%$. The problem with this approach is that cooling of the deep ocean during the LGM need not be distributed uniformly. A site in the southern Indian Ocean, currently affected strongly by AABW, could experience minor cooling and have a larger change in $\delta^{18} \mathrm{O}_{\mathrm{sw}}$ if net atmospheric transport of water toward the poles was lower during the LGM. A site in the central Atlantic could tolerate substantially more cooling through a change from NADW to $\mathrm{AABW}$, but experience a smaller change in $\delta^{18} \mathrm{O}_{\mathrm{sw}}$.

To obtain a globally averaged estimate for the minimum change in $\delta^{18} \mathrm{O}_{\mathrm{sw}}$, we use the compilation of benthic foraminiferal oxygen isotope data from 20 sites of Broecker (1986). The average glacialinterglacial difference in $\delta^{18} \mathrm{O}$ of benthic foraminifers for those 20 sites is $1.71 \%$ o, with relatively small variability $(\sigma=0.08 \%$ o). The water depths at these sites range from 2 to $4 \mathrm{~km}$ with an average depth of $3 \mathrm{~km}$. If the average potential temperature at a depth of $3 \mathrm{~km}$ for the Pacific and Indian Oceans is $1.5^{\circ} \mathrm{C}$, and the Atlantic is $2.5^{\circ} \mathrm{C}$ (Sverdrup et al., 1960), then the average potential temperature (weighted by area) for the world oceans at a depth of $3 \mathrm{~km}$ is $1.8^{\circ} \mathrm{C}$. This implies a maximum cooling of $3.5^{\circ} \mathrm{C}$ and a minimum average glacial-interglacial change in $\delta^{18} \mathrm{O}_{\mathrm{sw}}$ of $0.9 \%$ if seawater were everywhere at its freezing point.

Clearly it is difficult to extrapolate from a single site to a globally averaged estimate for the change in $\delta^{18} \mathrm{O}_{\text {sw }}$ (i.e., the ice volume component of the benthic $\delta^{18} \mathrm{O}$ record). However, a conservative assumption would be that the Indian and Pacific Oceans were not warmer than the Atlantic during the LGM. The interstitial waters from Site 925 suggest that the deep ocean in the tropical Atlantic at $3 \mathrm{~km}$ water depth cooled by $4^{\circ} \mathrm{C}$, within $1^{\circ}$ of the freezing point of seawater. If this is true for deep water in other ocean basins, then the global average change in $\delta^{18} \mathrm{O}_{\mathrm{sw}}$ since the LGM is approximately $1.0 \%$. Just as the cooling of the deep ocean need not be distributed evenly between ocean basins, this average change in $\delta^{18} \mathrm{O}_{\mathrm{sw}}$ need not be uniform. For example, if atmospheric transport of fresh water towards the Antarctic were reduced, there would be a larger change in $\delta^{18} \mathrm{O}_{\mathrm{sw}}$ (and a smaller change in temperature) in the Antarctic, consistent with the observations of Duplessy (1978), and slightly smaller changes in the Atlantic and Pacific.

A global average change in $\delta^{18} \mathrm{O}_{\mathrm{sw}}$ of $1.0 \%$ is also more consistent with independent estimates for the isotopic composition of continental ice during the LGM. If the average $\delta^{18} \mathrm{O}_{\text {sw }}$ during the LGM were $1.0 \%$ higher than today rather than $1.3 \%$, it would require the average $\delta^{18} \mathrm{O}$ value of continental ice to be $-32 \%$ rather than $-42 \%$ (Fairbanks, 1989), which agrees with the estimates of Olausson (1965), Shackleton (1967), Dansgaurd and Tauber (1969), Mix and Ruddiman (1984), and Mix (1987).

Another implication of a lower glacial-interglacial change in $\delta^{18} \mathrm{O}_{\text {sw }}$ is that it allows for greater cooling of the tropics during the LGM. By assuming an ice-volume component of $1.3 \%$, $\delta^{18} \mathrm{O}$ records of planktonic foraminifers imply that tropical sea surface temperatures were at most $2^{\circ}$ colder during the LGM (Broecker, 1986), consistent with estimates from CLIMAP (CLIMAP Project Members, 
1981). If the contribution of continental ice to the carbonate oxygen isotope record for the LGM is only $1.0 \%$ as a global average, and as low as $0.8 \%$ for parts of the Atlantic, then $\delta^{18} \mathrm{O}$ records of tropical planktonic foraminifers can yield from $3^{\circ} \mathrm{C}$ to $5^{\circ} \mathrm{C}$ of cooling at the LGM. This helps to reconcile tropical planktonic foraminiferal $\delta^{18} \mathrm{O}$ records with the coral $\delta^{18} \mathrm{O}$ and $\mathrm{Sr} / \mathrm{Ca}$ measurements of Guilderson et al. (1994), and with terrestrial climate proxies including snow-line elevations (Porter, 1979; Webster and Streten, 1978), noble gases in groundwater (Stute et al., 1992), and pollen records (Van der Hammen, 1974).

The pulse of high $\delta^{18} \mathrm{O}$ interstitial water from the LGM, used here to reconstruct $\delta^{18} \mathrm{O}_{\mathrm{sw}}$ during the LGM in the tropical Atlantic, should exist everywhere on the ocean floor where diffusion is the dominant transport mechanism in interstitial waters. Future work with highresolution interstitial water sampling on ODP drilling legs could map out spatial variability in $\delta^{18} \mathrm{O}_{\mathrm{sw}}$ (and $\delta \mathrm{D}$ ) during the LGM, both within and between ocean basins. In addition, a similar modeling approach could be applied to chloride data on interstitial waters to calculate the salinity of the deep ocean during the LGM; this was not possible for samples from Site 925 because of shipboard analytical difficulties.

\section{SUMMARY}

Interstitial waters from Site 925 in the tropical Atlantic indicate a glacial-interglacial change in the $\delta^{18} \mathrm{O}$ of seawater of $0.8 \pm 0.1 \%$. This implies that the deep ocean in the Atlantic cooled by $4^{\circ} \mathrm{C}$ during the LGM, which is consistent with greater dominance of AABW over NADW. It also implies that the modern temperature contrast between ocean basins was greatly reduced during the LGM. Although these data from a single site do not represent a global average, we suggest that the substantial cooling of deep water at Site 925 is consistent with a global average change in the $\delta^{18} \mathrm{O}$ of seawater of $1.0 \%$. This value is within the limits imposed by the freezing point of seawater and is more consistent with estimates of the $\delta^{18} \mathrm{O}$ of continental ice during the glacial maximum. In addition, a lower contribution from ice volume to the change in $\delta^{18} \mathrm{O}$ of planktonic foraminifers allows for $1^{\circ} \mathrm{C}$ to $2^{\circ} \mathrm{C}$ additional cooling in the tropics during the last glacial maximum over CLIMAP estimates, reconciling the foraminiferal oxygen isotope record of sea surface temperatures with estimates from Barbados corals and terrestrial climate proxies.

\section{ACKNOWLEDGMENTS}

We thank Don DePaolo for inspiration, Nick Shackleton and Bill Curry for dedicating Hole $925 \mathrm{E}$ to this project, and the entire Scientific Party of ODP Leg 154 for their patience and support. The manuscript was greatly improved from reviews by M. Delaney, N. Shackleton, A. Bath, and J. Gieskes. This work was partly supported by a grant from JOI-USSAC.

\section{REFERENCES}

Bard, E., Hamelin, B., Fairbanks, R.G., and Zindler, A., 1990. Calibration of the ${ }^{14} \mathrm{C}$ time-scale over the past 30,000 years using mass spectrometric U-Th ages from Barbados corals. Nature, 345:405-410.

Broecker, W.S., 1986. Oxygen isotope constraints on surface ocean temperatures. Quat. Res., 26:121-134.

CLIMAP Project Members, 1981. Seasonal reconstructions of the Earth's surface at the last glacial maximum. Geol. Soc. Am., Map and Chart Ser., MC36.

Curry, W.B., and Lohmann, G.P., 1990. Reconstructing past particle fluxes in the tropical Atlantic Ocean. Paleoceanography, 5:487-505.

Curry, W.B., Shackleton, N.J., Richter, C., et al., 1995. Proc. ODP, Init. Repts., 154: College Station, TX (Ocean Drilling Program).
Dansgaard, W., and Tauber, H., 1969. Glacier oxygen 18 content and Pleistocene ocean temperatures. Science, 166:499-502.

Duplessy, J.-C., 1978. Isotope studies. In Gribbin, J. (Ed.), Climate Change: Cambridge (Cambridge Univ. Press), 46-67.

Fairbanks, R.G., 1989. A 17,000-year glacio-eustatic sea level record: influence of glacial melting rates on the Younger Dryas event and deep-ocean circulation. Nature, 342:637-642.

Fairbanks, R.G., and Matthews, R.K., 1978. The marine oxygen isotope record in Pleistocene coral, Barbados, West Indies. Quat. Res., 10:181196.

Guilderson, T.P., Fairbanks, R.G., and Rubenstone, J.L., 1994. Tropical temperature variations since 20,000 years ago: modulating interhemispheric climate change. Science, 263:663-665.

Lawrence, J.R., and Gieskes, J.M., 1981. Constraints on water transport and alteration in the oceanic crust from the isotopic composition of pore water. J. Geophys. Res., 86:7924-7934.

Lynch-Steiglitz, J., Fairbanks, R.G., and Charles, C.D., 1994. Glacial-interglacial history of Antarctic intermediate water: relative strengths of Antarctic versus Indian Ocean sources. Paleoceanography, 9:7-29.

McDuff, R.E., 1985. The chemistry of interstitial waters, Deep Sea Drilling Project Leg 86. In Heath, G.R., Burckle, L.H., et al., Init. Repts. DSDP, 86: Washington (U.S. Govt. Printing Office), 675-687.

McDuff, R.E., and Gieskes, J.M., 1976. Calcium and magnesium profiles in DSDP interstitial waters: diffusion or reaction? Earth Planet. Sci. Lett., 33:1-10.

Mix, A.C., 1987. The oxygen-isotope record of glaciation. In Ruddiman, W.F., and Wright, H.E., Jr. (Eds.), North America and Adjacent Oceans During the Last Glaciation. Boulder, CO (Geol. Soc. Am.), K-3:111125.

Mix, A.C., and Ruddiman, W.F., 1984. Oxygen-isotope analyses and Pleistocene ice volumes. Quat. Res., 21:1-20.

Olausson, E., 1965. Evidence of climatic changes in north Atlantic deep sea cores, with remarks on isotopic paleotemperature analysis. Progr. Oceanogr., 3:221-252.

Porter, S.C., 1979. Hawaiian glacial ages. Quat. Res., 12:161-187.

Rind, D., and Peteet, D., 1985. Terrestrial conditions at the last glacial maximum and CLIMAP sea-surface temperature estimates: are they consistent. Quat. Res., 24:1-22.

Schrag, D.P., and DePaolo, D.J., 1993. Determination of $\delta^{18} \mathrm{O}$ of seawater in the deep ocean during the last glacial maximum. Paleoceanography, 8:16.

Shackleton, N., 1967. Oxygen isotope analyses and Pleistocene temperatures re-assessed. Nature, 215:15-17.

Shackleton, N.J., and Hall, M.A., 1989. Stable isotope history of the Pleistocene at ODP Site 677. In Becker, K., Sakai, H., et al., Proc. ODP, Sci. Results, 111: College Station, TX (Ocean Drilling Program), 295-316.

Shackleton, N.J., and Pisias, N.G., 1985. Atmospheric carbon dioxide, orbital forcing, and climate. In Sundquist, E.T., and Broecker, W.S. (Eds.), The Carbon Cycle and Atmospheric $\mathrm{CO}_{2}$ : Natural Variations Archean to Present. Geophys. Monogr., Am. Geophys. Union, 32:303-317.

Shemesh, A., Charles, C., and Fairbanks, R.G., 1992. Oxygen isotopes in biogenic silica: global changes in ocean temperature and isotopic composition. Science, 256:1434-1436.

Simpson, J.H., and Carr, H.Y.,1958. Diffusion and nuclear spin relaxation in water. Phys. Rev. 2nd Ser., 1201-1208.

Stute, M., Schlosser, P., Clark, J.F., and Broecker, W.S., 1992. Paleotemperatures in the Southwestern U.S. derived from noble gases in groundwater. Science, 256:1000-1003.

Sverdrup, H.U., Johnson, M.W., and Fleming, R. (Eds.), 1960. The Oceans: Their Physics, Chemistry and General Biology: Englewood Cliffs, NJ (Prentice-Hall).

Van der Hammen, T., 1974. The Pleistocene changes of vegetation and climate in tropical South America. J. Biogeogr., 1:3-26.

Webster, P.J., and Streten, N.A., 1978. Quaternary ice age climates of tropical Australia: interpretations and reconstructions. Quat. Res., 10:1027910309.

Date of initial receipt: 1 December 1995

Date of acceptance: 9 April 1996

Ms 154SR-128 